\title{
Pemberdayaan Kader Dalam Upaya Pencegahan Dan Penanggulangan Anemia Ibu Hamil
}

\author{
Frisca Dewi Yunadi ${ }^{1}$, Imam Agus Faizal ${ }^{2 *}$, Rochany Septiyaningsih ${ }^{3}$ \\ 1,3Program Studi S1 Kebidanan, STIKES Al-Irsyad Al-Islamiyyah Cilacap, Jalan Cerme No.24, Cilacap 53223 \\ ${ }^{2}$ Program Studi Sarjana Terapan Teknologi Laboratorium Medis, STIKES Al-Irsyad Al-Islamiyyah Cilacap, \\ Jalan Cerme No.24, Cilacap 53223 \\ *Email: imamdfaizal@stikesalirsyadclp.ac.id.
}

\begin{abstract}
Abstrak
Berdasarkan Riset Kesehatan Dasar 2018 prevalensi anemia pada ibu hamil mencapai 48,9\%. World Health Organization (WHO) melaporkan bahwa terdapat 52\% ibu hamil mengalami anemia di negara berkembang. Anemia pada kehamilan dapat menyebabkan dampak yang serius yang bisa terjadi pada saat hamil, bersalin dan postpartum. Pengabdian Masyarakat ini bertujuan untuk meningkatkan pemberdayaan kader dalam mencegah dan menanggulangi anemia. Pemberdayaan ini dilakukan dengan membekali kader terlebih dahulu dengan pengetahuan mengenai masalah dan besaran masalah anemia, dampak anemia, faktor penyebab, menu makanan pencegahan anemia dan tablet tambah darah. Tahap selanjutnya adalah mendampingi kader dalam mengalikasikan pengetahuan dan keterampilan yang diperoleh dalam Pendidikan kesehatan kepada ibu hamil. Berdasarkan hasil pengabdian didapatkan bahwa ada peningkatan pengetahuan tentang Anemia pada kelompok kader. Hasil post test menunjukkan adanya peningkatan rata-rata pengetahuan antara pre test dan post test. Hasil observasi kader Kesehatan dalam melakukan Pendidikan Kesehatan kepada ibu hamil di kelas ibu hamil masuk dalam katagori baik.
\end{abstract}

Kata kunci : Anemia, Kader, Kesehatan, Ibu Hamil

\begin{abstract}
Based on the 2018 Basic Health Research, the prevalence of anemia in pregnant women reached 48.9\%. The World Health Organization (WHO) reports that in developing countries, there are $52 \%$ of pregnant women experiencing anemia. Anemia in pregnancy can have serious effects that can occur during pregnancy, childbirth and postpartum. This community service aims to increase the empowerment of cadres in preventing and overcoming anemia. This empowerment is carried out by equipping cadres with knowledge of the problem and magnitude of the problem of anemia, the impact of anemia, causative factors, anemia prevention diet and blood supplement tablets. The next stage is to assist cadres in applying the knowledge and skills acquired in health education to pregnant women. Based on the results of the dedication, it was found that there was an increase in knowledge about anemia in the cadre group. The post test results showed an increase in the average knowledge between the pre test and post test. The results of observations by health cadres in carrying out health education for pregnant women in the class of pregnant women fall into the good category.
\end{abstract}

Keywords: Anemia, Cadre, Health, Pregnant Women 


\section{PENDAHULUAN}

Anemia merupakan masalah kesehatan masyarakat karena berhubungan dengan meningkatnya risiko morbiditas dan mortalitas pada saat ibu melahirkan (Demmouche, A., Khelil, S. \& Moulesehoul, 2011). World Health Organization (WHO) melaporkan bahwa terdapat $52 \%$ ibu hamil mengalami anemia di negara berkembang. Anemia pada kehamilan dapat menyebabkan dampak yang serius yang bisa terjadi pada saat hamil, bersalin dan postpartum. Anemia pada kehamilan adalah bila kadar hemoglobin $(\mathrm{Hb})<11$ gr\% pada trimester 1 dan 3 atau kadar haemoglobin 10,5gr\% pada trimester 2 (Saifuddin AB, 2009). Ibu hamil yang menderita anemia memiliki peluang mengalami perdarahan pada saat melahirkan yang dapat berakibat pada kematian. Salah satu dampaknya adalah perdarahan postpartum. Berdasarkan penelitian bahwa ada hubungan anemia dengan kejadian perdarahan pasca persalinan ( $\mathrm{p}=0,00<\alpha=0,05$ ) dan nilai $\mathrm{OR}=6.00$ (Yunadi et al., 2019) sehingga hasil tersebut penting untuk mengantisipasi terjadinya perdarahan yang disebabkan oleh anemia karena perdarahan merupakan penyumbang dari kematian ibu terbanyak.

Angka Kematian Ibu (AKI) adalah salah satu dari indikator dalam mengukur derajat kesehatan pada perempuan. AKI di Indonesia masih tinggi, jauh di bawah target yaitu sebanyak 305/100.000 Kelahiran hidup (KH), padahal target dari Sustainable Development Goals (SDGs) yaitu menurunkan AKI sebanyak kurang dari 70/100.000 Kelahiran Hidup (KH). AKI di Provinsi Jawa Tengah cenderung menurun dari tahun ke tahun, yaitu pada tahun 2017 sebesar 475 kasus $(88,05 / 100.000 \mathrm{KH})$, mengalami penurunan dibandingkan pada tahun 2016 yaitu sebanyak 602 kasus $(109,65 / 100.000 \mathrm{KH})$ dan pada tahun 2015 sebanyak 619 kasus. Kepala Seksi Kesehatan keluarga dan Gizi Dinas Kesehatan Kabupaten Cilacap melaporkan bahwasanya angka kematian Ibu atau AKI pada periode tahun 2019 ada sebanyak 15 kasus. Sedangkan jumlah kematian bayi atau AKB mencapai 155 kasus (Kementrian Kesehatan Republik Indonesia, 2019). Salah satu penyebab AKI terbesar adalah perdarahan. Penyebab perdarahan antara lain adalah anemia pada kehamilan.

Anemia selama kehamilan utamanya disebabkan karena kekurangan zat besi (Fe). Kekurangna mikronutrien seperti asam folat, vitamin A, dan vitamin B12 (Haider et al., 2013). WHO telah lama merekomendasikan pemberian suplemen zat besi pada ibu hamil terutama di negara berpenghasilan rendah dan berpenghasilan tinggi. Faktor-faktor yang dapat mempengaruhi kejadian pada kekurangan energi kronis (KEK) pada ibu hamil diantaranya faktor langsung diantaranya asupan makanan dan infeksi patogen. Sedangkan faktor tidak 
langsung diantaranya faktor sosial ekonomi yang meliputi pendapatan, pekerjaan, pendidikan, pengetahuan, usia, jarak kehamilan dan faktor perilaku (Supariasa, 2002). Selain itu pengetahuan ibu hamil tentang anemia sangat penting untuk mengetahui penyebab, tanda, gejala anemia dan makanan untuk mencegah anemia sangat kurang (Yadav et al., 2014). Upaya penurunan AKI membutuhkan aksi pada beragam level, dari tingkat daerah sampai pusat termasuk didalamnya adalah peran serta masyarakat melalui kegiatan posyandu (UNFPA, 2005). Selain posyandu, kelas ibu hamil juga merupakan kelompok yang efektif untuk meningkatkan pengetahuan dan sikap ibu hamil dalam mengenali risiko dan tanda bahaya dalam kehamilan (Purwaningsih, 2010).

Berdasarkan hal tersebut, maka tim dosen STIKES Al-Irsyad Al-Islamiyyah Cilacap bermaksud untuk mengadakan pengabdian kepada masyarakat yang betujuan untuk meningkatkan kesehatan ibu hamil melalui "Pemberdayaan Kader Dalam Upaya Pencegahan Dan Penanggulangan Anemia Ibu Hamil Di Desa Menganti Kabupaten Cilacap”.

\section{MASALAH}

Pengetahuan merupakan determinan penting dalam perubahan perilaku kesehatan dan bagi ibu hamil. Pengetahuan tentang kehamilan sebenarnya bisa dengan mudah ibu hamil dapatkan lewat peran kader kesehatan. Namun, kader kesehatan itu sendiri tidak semua paham mengenai masalah anemia pada ibu hamil. Pengabdian Masyarakat dilakukan dengan melakukan pemberdayaan kader dalam upaya pencegahan dan penanggulangan Anemia pada ibu hamil, sehingga kader bisa mengaplikasikannya pada saat Posyandu kepada ibu hamil. Kader kesehatan akan dilakukan pelatihan berupa transfer pengetahuan mengenai masalah dan besaran masalah anemia, dampak anemia, faktor penyebab, menu makanan pencegahan anemia dan tablet tambah darah. Angka kejadian di Desa Menganti sendiri cukup tinggi sedangkan kader kesehatan di Desa Menganti belum pernah diberikan penyuluhan mengenai anemia, padahal kader adalah mitra dari tenaga Kesehatan yang paling dekat dengan masyarakat.

\section{METODE}

Berdasarkan analisis situasi dan permasalahan di atas tim pengusul kegiatan Pengabdian Masyarakat berkeinginan membantu mitra meningkatkan pengetahuan dan kemampuan kader dalam pencegahan dan penanggulangan Anemia pada ibu hamil. Metode 
yang digunakan dalam pengabdian adalah metode pembelajaran orang dewasa yaitu dinamika kelompok, ceramah tanya jawab dan simulasi. Untuk memantau peningkatan pengetahuan kader yang digunakan adalah pre post dan post test. Post test dilakukan sebanyak 2 kali dengan selang waktu 2 minggu.

1) Pelatihan kader dengan tema utama peningkatan peran dan fungsi kader posyandu dalam mengenali pencegahan dan penanggulangan anemia ibu hamil di Desa Menganti Kabupaten Cilacap. Dengan memiliki pengetahuan tersebut diharapkan kader dapat diberdayakan untuk membantu pelaksanaan program sekaligus sebagai penggerak dalam bidang kesehatan ibu hamil di wilayahnya dan pada akhirnya dapat meningkatkan fungsi posyandu secara optimal.

2) Pelatihan dilakukan selama dua hari di masing-masing desa sasaran, dengan materi meliputi: Pengertian masalah dan besaran masalah anemia, faktor penyebab anemia, menu makan pencegah anemia dan tablet tambah darah.

3) Evaluasi Program untuk menilai keberhasilan program dalam rangka meningkatkan pengetahuan kader posyandu dilakukan dengan membandingkan nilai pre test dan post test sesuai dengan materi yang diberikan. Kemudian dilaksanakan evaluasi melalui observasi kader untuk melakukan konseling ke ibu hamil di kelas ibu hamil yang dilaksanakan 2 minggu setelah pelatihan.

\section{HASIL DAN PEMBAHASAN}

1) Hasil

Hasil kegiatan program pengabdian kepada masyarakat terkait Pemberdayaan Kader Dalam Upaya Pencegahan Dan Penanggulangan Anemia Ibu Hamil Di Desa Menganti Kabupaten Cilacap dilakukan dengan dua metode yaitu:

a. Pre test

Tabel 1.

Distribusi Frekuensi Pengetahuan Kader Sebelum Diberikan Pendidikan Kesehatan tentang Anemia

\begin{tabular}{llll}
\hline No. & Pengetahuan & Frekuensi & Persen \\
\hline 1. & Baik & 7 & 35 \\
2 & Cukup & 13 & 73 \\
3 & Kurang & 1 & 2 \\
\hline Jumlah & & 21 & 100 \\
\hline
\end{tabular}

Berdasarkan tabel 1. maka diketahui bahwa pengetahuan kader sebelum diberikan 
pendidikan kesehatan tentang anemia sebagian besar mempunyai pengetahuan katagori baik sebanyak 7 orang (35\%), cukup sebanyak 13 orang (73\%) dan kurang 1 orang (2\%). Pengukuran pengetahuan dilakukan dengan meminta kader desa Menganti untuk mengisi kuesioner yang berisi 21 pertanyaan seputar anemia. Hasil nilai rata-rata pengetahuan kader adalah 61.

b. Post Test

Tabel 2.

Distribusi Frekuensi Pengetahuan Kader Sesudah Diberikan Pendidikan Kesehatan tentang Anemia

\begin{tabular}{llll}
\hline No. & Pengetahuan & Frekuensi & Persen \\
\hline 1. & Baik & 19 & 92 \\
2 & Cukup & 2 & 9 \\
3 & Kurang & 0 & 0 \\
\hline Jumlah & & 21 & 100 \\
\hline
\end{tabular}

Berdasarkan tabel 4.2. maka diketahui bahwa pengetahuan kader sesudah diberikan pendidikan tentang anemia sebagian besar mempunyai pengetahuan katagori baik yang sangat signifikan yaitu sebanyak 18 orang (92\%), cukup sebanyak 2 orang (10\%) dan dan katagori kurang sebanyak 0 orang (0\%). Pengukuran pengetahuan dilakukan melalui kuesioner yang digunakan pada saat pre test. Hasil nilai rata-rata pengetahuan kader adalah 88 .

c. Metode presentasi tentang Anemia pada Kehamilan yang disampaikan oleh anggota pelaksana pengabdian a.n Frisca Dewi Yunadi kepada kader desa Menganti.

d. Evaluasi konseling kader tentang “Anemia Pada Kehamilan kepada Ibu Hamil” yang diwakilkan/sampling oleh 4 kader Kesehatan yang memiliki nilai pre test baik dan kurang. Hasil kader mampu menjelaskan Anemia Pada Kehamilan dengan benar.

e. Evaluasi kedua dilakukan dengan observasi kemampuan kader dalam melakukan penyuluhan dan konseling tentang Anemia kepada ibu hamil. Hasilnya seluruh kader berhasil melakukan penyuluhan dan konseling.

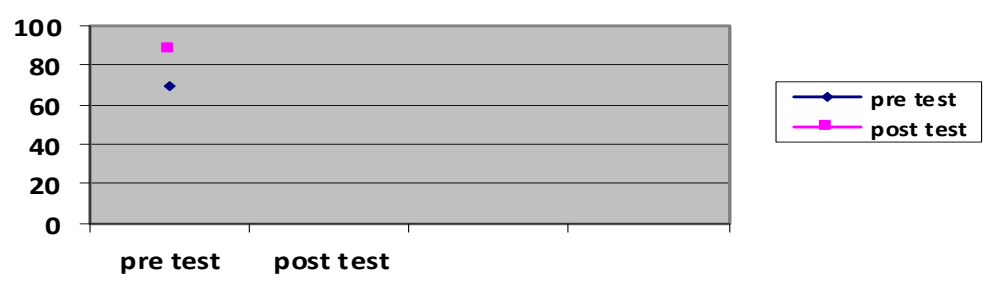

Gambar 1. Peningkatan Pengetahuan Kader 


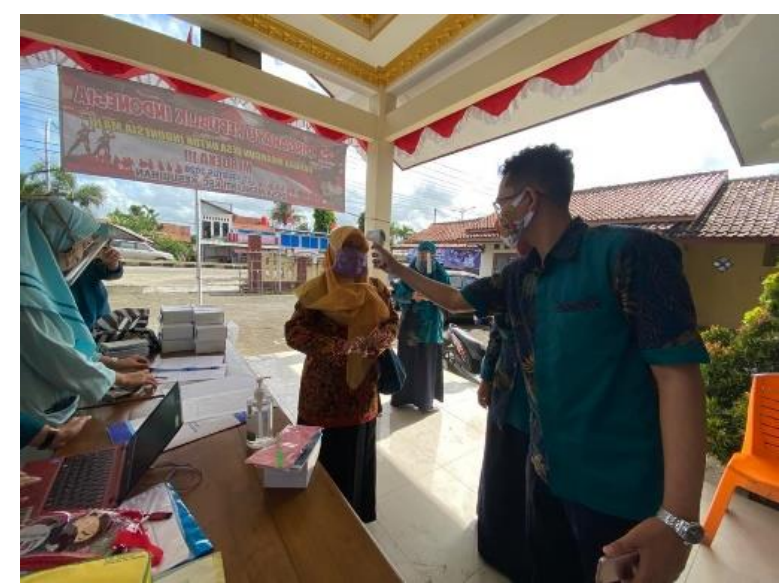

Gambar 2. Pemeriksaan Suhu Tubuh

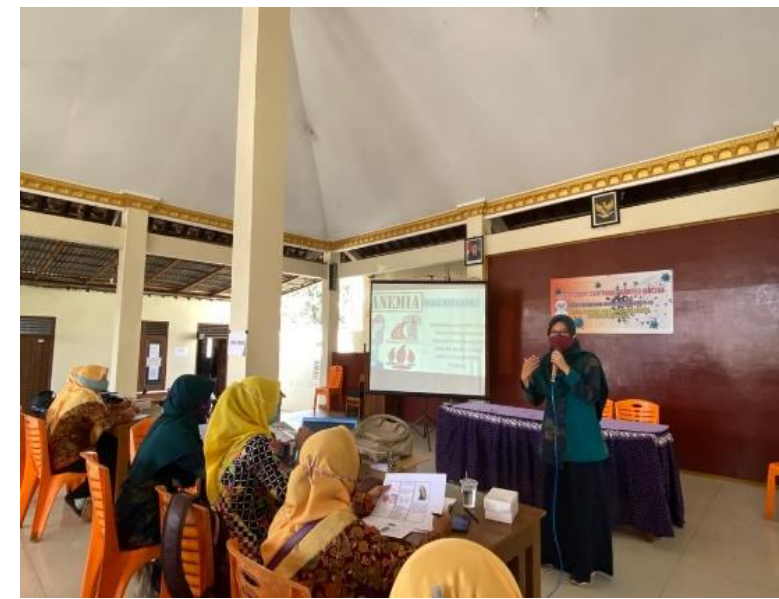

Gambar 4. Pemberian Materi dan Diskusi

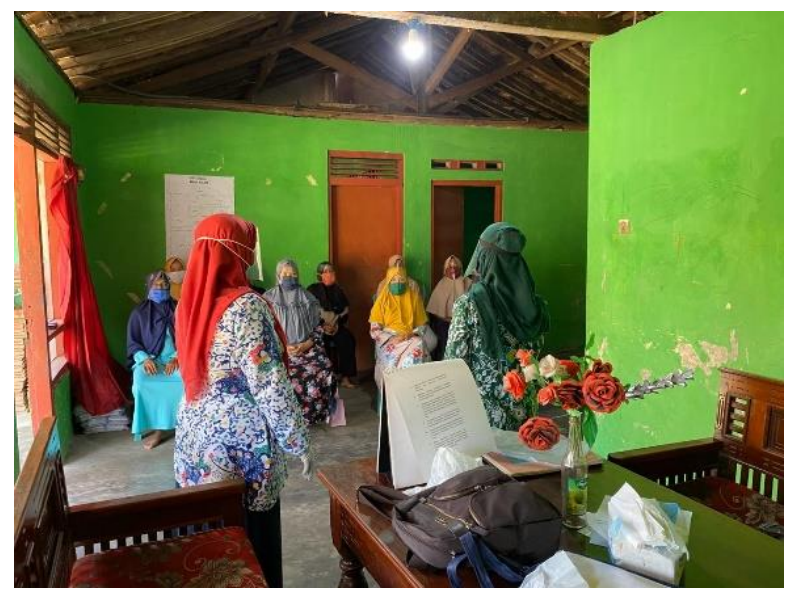

Gambar 6. Observasi Konseling dan penyuluhan yang dilakukan oleh kader tentang Anemia

\section{2) Pembahasan}

Evaluasi kegiatan pengabdian masyarakat dilakukan untuk mengukur keberhasilan dari program pengabdian masyarakat. Evaluasi kegiatan dilakukan dengan dua metode yaitu

Jurnal Pengabdian Masyarakat Al-Irsyad Vol. II, No. 2. Oktober 2020 
metode post test (tanya jawab dan mengisi kuesioner) kepada kader tentang Anemia pada kehamilan. Selain dengan tanya jawab dan mengisi kuesioner, evaluasi keberhasilan program pengabdian masyarakat dengan metode observasi pada waktu kader menjelaskan tentang Anemia pada kehamilan pada Ibu Hamil yang benar. Pemberian materi memberikan wacana baru akan pengetahuan terhadap upaya pemahaman materi kami lakukan dengan mengefektifkan diskusi. Beberapa faktor pendukung terlaksananya kegiatan pengabdian masyarakat ini dengan baik antara lain:

a. Jumlah peserta tercapai sesuai dengan sasaran peserta. Tingginya motivasi peserta untuk mengikuti seluruh rangkaian kegiatan.

b. Tingginya antusias dan minat peserta dalam mendengarkan dan memperhatikan materi terbukti dengan banyaknya pertanyaan yang diajukan selama proses kegiatan.

c. Fasilitas yang cukup memadai yang telah disediakan oleh panitia penyelenggara pelatihan penanganan diare pada balita.

d. Dukungan penuh dari Pimpinan STIKES dan UPT PPM STIKES Al-Irsyad AlIslamiyyah Cilacap membuat semangat tersendiri hingga tercapainya kesuksesan kegiatan ini.

Pendidikan kesehatan merupakan suatu upaya atau kegiatan untuk menciptakan perilaku masyarakat yang kondusif untuk kesehatan. Artinya, masyarakat menyadari atau mengetahui bagaimana cara memelihara kesehatan dan menghindari atau mencegah hal-hal yang merugikan kesehatan (Notoatmodjo. S., 2012). Proses belajar dalam pendidikan kesehatan merupakan proses terjadinya perubahan kemampuan pada subjek belajar dengan keluaran yang diharapkan adalah kemampuan sebagai hasil perubahan perilaku dari sasaran didik (Notoatmodjo, 2010). Peningkatan pengetahuan yang terjadi pada kader kesehatan setelah diberikan pendidikan kesehatan merupakan salah satu aspek kemampuan yang dicapai oleh sasaran didik sebagai akibat adanya proses belajar. Pencapaian tujuan pendidikan kesehatan akan lebih mudah dengan penggunaan media pembelajaran yang sesuai dan dapat meningkatkan kemudahan penerimaan informasi. Seperti yang dilakukan dalam pengabdian masyarakat ini menggunakan media leaflet dan diskusi. Faktor utama yang mempengaruhi perilaku kesehatan pada ibu hamil adalah pengetahuan dan diikuti dengan pemahaman anemia serta cara mencegah anemia akan mempunyai perilaku dan tindakan yang positif sehingga dengan dibekali pengetahuan dan pemahaman maka dapat terhindar dari dampak dan risiko anemia pada masa kehamilan (Purbadewi et al., 2013). 
Hasil post test menunjukkan bahwa rata-rata tingkat pengetahuan kader tentang Anemia Pada Kehamilan setelah pendidikan kesehatan meningkat/ lebih tinggi dibanding rata-rata sebelum penyuluhan. Perbedaan ini bermakna bahwa perlakuan yang berupa penyuluhan dapat meningkatkan pengetahuan kader tentang anemia pada kehamilan. Penyuluhan kesehatan adalah kegiatan pendidikan kesehatan yang dilakukan dengan menyebarkan pesan dan menanamkan keyakinan bertujuan agar masyarakat lebih tahu, sadar, serta bisa melakukan suatu anjuran yang diberikan ada hubungannya dengan kesehatan. Adanya peningkatan tingkat pengetahuan kader tentang anemia pada kehamilan setelah diberikan pendidikan kesehatan juga didukung oleh beberapa hal, antara lain tingkat pengetahuan kader sebelum pendidikan kesehatan sebagian besar memang sudah memiliki pengetahuan cukup karena anemia merupakan masalah yang sering ditemui di masyarakat. Pengetahuan yang pernah didapatkan dan disimpan dalam memori kader kemudian ditimbulkan kembali dengan pendidikan kesehatan. Hasil penelitian bahwasannya ditemukan bahwa Ibu yang memiliki pengetahuan rendah lebih berisiko mengalami anemia 2,9 kali dibandingkan Ibu yang memiliki pengetahuan baik sehingga menunjukkan bahwa pengetahuan Ibu hamil merupakan faktor risiko kejadian anemia pada Ibu hamil. Selain itu pengetahuan Ibu yang kurang berkorelasi dengan kejadian dengan anemia pada Ibu dengan jenis pekerjaan Ibu (Amanupunnyo et al., 2018). Penyuluhan kesehatan tentang anemia pada kehamilan merupakan tahap awal bertambahnya wawasan atau pengetahuan seseorang yang dapat membentuk sikap dalam pencegahan anemia. Penyuluhan yang intensif, menarik dan mudah dipahami dapat menambah pengetahuan kader yang baik tentang anemia pada kehamilan maka akan direspon secara positif oleh kader paling tidak dari sikapnya terlebih dahulu sebelum diwujudkan dalam bentuk perilaku (practice). Demikian juga semakin jarang diadakan penyuluhan kesehatan, pengetahuan kader tentang anemia pada kehamilan juga kurang maka sebagian besar juga memiliki sikap negatif dalam pencegahan anemia. Ibu hamil yang mengetahui dan memahami akibat anemia serta cara mencegah anemia akan mempunyai perilaku dan tindakan yang positif sehingga dapat terhindar dari dampak dan risiko anemia pada masa kehamilan. Menyatakan bahwa pengetahuan yang baik akan akan mempengaruhi perilaku kesehatan sehingga berpengaruh terhadap perilaku kesehatan (Sulistyoningsih, 2011). Perilaku tingkat kesehatan pada ibu hamil menerut penelitian ada kaitannya dengan tingkat pendidikan. Semakin tinggi tingkat pendidikan semakin mudah menerima konsep hidup sehat secara mandiri, kreatif dan berkesinambungan. Tingkat Pendidikan juga sangat 
mempengaruhi kemampuan dalam menerima informasi gizi, menentukan atau mempengaruhi mudah tidaknya seseorang menerima suatu pengetahuan, semakin tinggi pendidikan maka seseorang akan lebih mudah menerima informasi gizi sehingga perkembangan ibu hamil memiliki risiko anemia yang rendah (Chandra et al., 2019).

Faktor penghambat selama kegiatan adalah faktor keterbatasan biaya dan tenaga yang tersedia, sehingga kita tidak dapat memantau sepenuhnya pasca kegiatan ini. Kegiatan ini hanya terpantau dari tingkat pemahaman materi pelatihan yang disajikan, namun pemantauan pasca kegiatan semacam kegiatan pendampingan atau pembinaan belum dapat terlaksana. Hal ini juga ditambah dengan adanya Pandemi yang terjadi sehingga ruang gerak sangat terbatas.

\section{KESIMPULAN}

Pengabdian masyarakat yang dilaksanakan oleh para dosen STIKES Al-Irsyad AlIslamiyyah Cilacap Pemberdayaan Kader Dalam Upaya Pencegahan Dan Penanggulangan Anemia Ibu Hamil Di Desa Menganti Kabupaten Cilacap dapat terselenggara dengan baik dan lancar sesuai dengan jadwal yang direncanakan. Dari kegiatan penyajian materi, diskusi dan pelatihan dapat dipantau adanya peningkatan wawasan, pemahaman dan kemampuan para peserta yang signifikan dari total 21 kader sebanyak 18 orang (92\%), cukup sebanyak 2 orang $(10 \%)$ dan dan katagori kurang sebanyak 0 orang (0\%) dengan nilai mean sebanyak 88.

\section{DAFTAR PUSTAKA}

Amanupunnyo, N. A., Shaluhiyah, Z., \& Margawati, A. (2018). Analisis Faktor Penyebab Anemia pada Ibu Hamil di Puskesmas Kairatu Seram Barat. Jurnal Aisyah : Jurnal Ilmu Kesehatan, 3(2), 173-181. https://doi.org/10.30604/jika.v3i2.134

Chandra, F., Junita, D. D., \& Fatmawati, T. Y. (2019). Tingkat Pendidikan dan Pengetahuan Ibu Hamil dengan Status Anemia. Jurnal Ilmiah Ilmu Keperawatan Indonesia, 9(04), 653-659. https://doi.org/10.33221/jiiki.v9i04.398

Demmouche, A., Khelil, S. \& Moulesehoul, S. (2011). Anemia Among Pregnant Women in the Sidi Bel Abbels Region (West Algaria). Journal An Epidemiologic Study. https://doi.org/doi:10.4172/2155-9864.1000113

Haider, B. A., Olofin, I., Wang, M., Spiegelman, D., Ezzati, M., \& Fawzi, W. W. (2013). Anaemia, prenatal iron use, and risk of adverse pregnancy outcomes: Systematic review and meta-analysis. In BMJ (Online) (Vol. 347, Issue 7916). BMJ Publishing Group. https://doi.org/10.1136/bmj.f3443 
Kementrian Kesehatan Republik Indonesia. (2019). Profil Kesehatan Indonesia 2018. Kementrian Kesehatan Republik Indonesia.

Notoatmodjo. S. (2012). Promosi Kesehatan dan Perilaku Kesehatan. Rineka Cipta.

Notoatmodjo, S. (2010). Kesehatan Masyarakat Ilmu \& Seni. Rineka Cipta.

Purbadewi, L., Noor, Y., Ulvie, S., Fakultas, S. G., Keperawatan, I., \& Kesehatan, D. (2013). Hubungan Tingkat Pengetahuan Tentang Anemia Dengan Kejadian Anemia Pada Ibu Hamil. In Jurnal Gizi (Vol. 2, Issue 1). https://doi.org/10.26714/JG.2.1.2013.\%P

PURWANINGSIH, T. (2010). FAKTOR-FAKTOR RISIKO HIPERURISEMIA(Studi kasus di Rumah Sakit Umum Kardinah Kota Tegal).

Saifuddin AB. (2009). Panduan Praktis Pelayanan Kesehatan Maternal dan Neonatal. EGC.

Sulistyoningsih, H. (2011). Gizi Untuk Kesehatan Ibu Dan Anak. Graha Ilmu.

Supariasa, dkk. (2002). Penilaian Status Gizi. Penerbit Buku Kedokteran EGC.

UNFPA. (2005). Kebijakan dan Strategi Nasional Pembangunan Kesehatan Reproduksi di Indonesia.

http://indonesia.unfpa.org/application/assets/publications/Kebijakan_Strategi_Nasional_ Kesehatan_Reproduksi_di_Indonesia.pdf.pdf

Yadav, R. K., Swamy, M. ., \& Banjade, B. (2014). Knowledge and Practice of Anemia among pregnant women attending antenatal clinic in Dr. Prabhakar Kore hospital, Karnataka-A Cross sectional study. IOSR Journal of Dental and Medical Sciences, 13(4), 74-80. https://doi.org/10.9790/0853-13477480

Yunadi, F. D., Septiyaningsih, R., Andhika, R., Al-Irsyad, S., \& Cilacap, A.-I. (2019). The Relationship Of Anemia With The Postpartum Hemorrhage. In Jurnal Kesehatan AlIrsyad: Vol. XII (Issue 2). http://stikesalirsyadclp.ac.id/jka/index.php/jka/article/view/153 